\section{Duesberg on AIDS and HIV}

SIR-Pinching et al. cite' their unpublished cohort studies of HIV-positive and negative homosexuals and haemophiliacs as epidemiological proof for "a pathogenic role for HIV infection", but, cohort studies are biased by those who recruit and by those who volunteer to be recruited. Before I could accept their conclusion, I would need to know for what "recreational drug use ... the two groups were closely matched" and what AIDS-linked diseases they developed whether, for example, Kaposi's sarcoma was observed in homosexuals and haemophiliacs, or only in homosexuals. But it is surprising that, among $120 \mathrm{HIV}$-negative "sexually active homosexual men" and 15 HIV-negative "severe haemophilia A subjects", not even one developed any of the 25 indicator diseases of AIDS in six years. Could it be that these diseases were not listed because in the absence of HIV they are called by their old names?

Further, the conclusion of Pinching et $a l$. is difficult to reconcile with published epidemiological data. Since 1985, about a million people in the United States have been estimated by the Centers for Disease Control to be HIV-positive, yet not more than about 70,000 ( 7 per cent) have died and about 117,000 (12 per cent) have developed AIDS in the past 10 years ${ }^{2}$. Moreover, about 15,000 people in the United States with severe haemophilia have been infected with HIV for about 10 years, the presumed average latent period for HIV. Yet during the past two years only 300 , or fewer than 2 per cent, have died annually with a diagnosis of AIDS.

Thus US HIV-positives seem to have fared much better than Pinching et al.'s cohorts. Indeed, recent controlled studies have shown that HIV-free haemophiliacs have the same immunodeficiencies as HIV-positive controls and at the same rate $^{5 .}$, and that HIV-free male homosexuals have the same Kaposi's sarcomas and some of the same T-cell deficiencies as HIV-positive controls?

\section{Apart from that...}

SIR - I was dismayed to read the letter on AIDS by A. Karpas (Nature 348, 578; 1990). The speculation contained therein is unfounded and unnecessary. The letter is a series of non sequiturs. Such ramblings are nonsensical and possibly hurtful. The decision to submit and to publish this letter is reprehensible.

Division of Human Retrovirology,

Dana-Farber Cancer Institute,

Harvard Medical School,

44 Binney Street,

Boston, Massachusetts 02115, USA
This, in my opinion, is why it is necessary to conduct randomized, controlled studies, instead of studying selected cohorts, to determine whether health risk factors, such as "recreational drugs" and "severe haemophilia" can cause AIDS without HIV, and whether HIV can cause AIDS without such factors.

Peter H. Duesberg

University of California, Berkeley,

Department of Molecular and Cell

Biology,

c/o Stanley/Donner Administrative

Services Unit,

Berkeley,

California 94720, USA

1. Weiss, R. A. \& Jaffe, H. W. Nature $345,659-660$ (1990). . Duesberg, P. H. Nature 346, 788 (1990),

Pinching, A. J., Jeffries, D. J., Harris, J. R. W., Swirsky, D. \& Weber, J. N. Nature 347. 24 (1990).

4. US Dept of Health and Human Services, Centers for Disease Control HIV/AIDS Surveillance (January 1990).

5. Jin, Z., Cleveland, R. P. \& Kaufman, D. B. J. Allergy clin Immun. 83, 165-170 (1989)

. Madhok, R. et al. Br. med. J. 293, 978-980 (1986)

7. Friedman-Kien, A. E. et al. Lancet 335, 168-169 (1990)

Marion, S. A. J. Acquired Immune Deficiency Syndrome 2 $178-186(1989)$

\section{Feel the draft}

SIR-Your analysis of "Conceptual sovereignty problems" (Nature 348, 467; 1990 ) is flawed at the outset by an historical error: "The monarch ... would conscript an army of serfs ...".

Monarchy, at least in the Middle Ages and in modern times in Europe, has never known conscription. In the Middle Ages, armies consisted of noblemen, vassals called to service by their suzerain; a king could call the vassals of his vassals ("l'arrière-ban"). Serfs were specifically excluded from military service, as had been slaves in antiquity. When an army of knights came to show its inefficiency, at Agincourt and other places, it was progressively replaced by professional armies with long-term, volunteer service. The last time the King of France called the "arrière-ban" was in the black year of 1709. To this day, Britons, having the privilege of being ruled by a sovereign, are immune from conscription except in desperate circumstances.

Conscription was invented by the French Revolution from necessity, France having declared war on Europe and most noblemen having emigrated or had their heads cut off. Another factor was reference to the "democracies" or republics of antiquity, where an army of conscripted free men (that is, slave owners) was necessary, among other things, to keep slaves from overthrowing their masters.

In fact, your argument could be correct in a roundabout way. 'Democracies' (whatever this much-abused word may mean) seem constitutionally incapable of peacefully coordinated action, not to speak of federation (it took the Sonderbund war to create model, modern Switzerland, and the ugly war between the states really to unite the United States). The nearest thing to unity Europe has known since the fall of the Roman Empire had been created by the conscripted armies of that heir to the French Revolution, Napoleon; mercifully, it did not last, any more than did the empire created by Stalin's (also conscripted) armies. Only when identity and sovereignty were both subsumed in a monarch (or, less well, in a proud elite of burghers) have their conflicts been resolved. The modern solution, alas, seems to be force and conquest: shotgun federation in the true sense of the word.

Laboratoire Montyon-La Salpétrière

47 Boulevard de l'Hopital,

75651 Paris Cedex 13 .

France

\section{Radiation doses}

SIR-There is no sense in the reduction of permissible radiation dose limits recommended by the International Commission on Radiological Protection as reported by Peter Aldhous and Seth Shulman (Nature 348, 274; 1990).

The long-running studies reporting a three times higher risk to irradiated survivors of Hiroshima and Nagasaki have been concerned with the more heavily irradiated individuals and a linear extrapolation of risks to doses in the millisievert range; this is no more valid than to suppose that consumption of a single aspirin tablet must lead to a half per cent risk of death because 200 aspirins taken together would be reliably lethal.

Among the Japanese bomb survivors, no observable excesses of cancer deaths were recorded for those receiving less than 50 rem $(0.5 \mathrm{~Sv})$.

In my view, the conclusion of the Gardner report, which linked leukaemia in children with the radiation exposure of their fathers, has many arguments against it. For example, the natural background in Kerala in India and in parts of Brazil equalled the dose recorded for the fathers quoted by Gardner, with no corresponding increase in childhood leukaemias among the children of visitors to those areas.

I find it disturbing that so much more attention is constantly given to the very improbable risks of low radiation doses than to the real dangers of air pollution by vehicle exhausts and coal burning. Such air pollution is probably responsible for more than 10,000 deaths a year in Britain alone.

J. H. FREMLIN

46 Vernon Road, Edgbaston,

Birmingham B16 9SH, UK

NATURE - VOL 350 - 7 MARCH 1991 